\title{
Serological evidence of herpes simplex virus infection in atopic eczema
}

\author{
T J DAVID, S J RICHMOND, AND A S BAILEY \\ Departments of Child Health and Virology, University of Manchester, Booth Hall Children's Hospital, \\ Manchester
}

SUMMARY Twenty three of 113 patients (20\%) with atopic eczema had neutralising antibodies to herpes simplex virus compared with 34 of 113 matched controls $(30 \%)$, an insignificant difference. This suggests that children with atopic eczema are no more likely to acquire herpes simplex infection than normal children.

While patients with atopic eczema are notoriously susceptible to severe skin infections with the herpes simplex virus, ${ }^{1}$ it is not clear whether they are more prone to herpes simplex infection than children of the same age without atopic eczema. We therefore looked for serological evidence of herpes simplex infection in a group of children with atopic eczema and compared the seropositivity rate at different ages with control children of the same age and sex admitted to hospital .

\section{Patients and methods}

from whom blood was taken specifically because of herpes simplex infection were excluded.

These patients with atopic eczema were matched against children of the same age and sex from the catchment area of the North Manchester Regional Virus Laboratory, who were referred to hospital during the study period and from whom blood was taken to exclude virus infection. The request cards accompanying the blood specimens were examined, and if eczema, herpes simplex, or malignant disease were mentioned the specimen was excluded.

Complement dependent serum neutralising antibodies to herpes simplex virus type 1 (strain $\mathrm{VR}_{3}$ ) were detected by a modification of the microneutralisation test of Pauls and Dowdle. ${ }^{2}$ Heat inactivated serum samples were tested in quadruplicate at dilutions of $1: 5$ and $1: 10$. Any serum that contained neutralising antibodies at a dilution of $1: 5$ was regarded as seropositive.

\section{Results}

Patients with atopic eczema from the north west of England who attended the department of child health at our hospital were studied. Blood was routinely taken at the first visit from those most severely affected to exclude immune deficiency and to estimate the serum IgE concentration. Serum samples from 121 consecutive patients ( 81 boys and 40 girls) collected between January 1982 and July 1984 were available for study. No special enquiries were made about a previous history suggestive of herpes simplex infection, but a further five patients

The results are summarised in the Table. When findings in children aged 6 months or less were excluded (as their antibodies were probably maternal in origin) 23 of the 113 patients $(20 \%)$ had antibodies to herpes simplex virus compared with 34 of the 113 controls $(30 \%)$. The difference between the two groups was insignificant $\left(\chi^{2}=2 \cdot 34, p=0 \cdot 12\right)$. Patients over the age of 6 months showed a progressive increase in the incidence of antibodies to the virus with age, whereas the increasing incidence with age was less consistent in the control group.

Table Neutralising herpes simplex virus antibodies in children with atopic eczema and control children

\begin{tabular}{|c|c|c|c|c|c|c|c|c|}
\hline \multirow[t]{2}{*}{ Age } & \multicolumn{4}{|c|}{ Patients } & \multicolumn{4}{|c|}{ Controls } \\
\hline & Boys & Girls & Total & $(\%)$ & Boys & Girls & Total & $(\%)$ \\
\hline$<7$ months & $0 / 4$ & $3 / 4$ & $3 / 8$ & $(37)$ & $4 / 4$ & $1 / 4$ & $5 / 8$ & $(62)$ \\
\hline $7-23$ months & $1 / 25$ & $0 / 10$ & $1 / 35$ & (3) & $4 / 25$ & $4 / 10$ & $8 / 35$ & (23) \\
\hline $2-4$ years & $7 / 30$ & $3 / 16$ & $10 / 46$ & $(22)$ & $6 / 30$ & $10 / 16$ & $16 / 46$ & (35) \\
\hline $5-14$ years & $10 / 22$ & $2 / 10$ & $12 / 32$ & (37) & $5 / 22$ & $5 / 10$ & $10 / 32$ & (31) \\
\hline Total* & $18 / 77$ & $5 / 36$ & $23 / 113$ & $(20)$ & $15 / 77$ & $19 / 36$ & $34 / 113$ & (30) \\
\hline
\end{tabular}

*Not including subjects under 7 months (see text). 


\section{Discussion}

As in any hospital based study the patients in this report were selected because their eczema was either unusually severe or particularly refractory to treatment. Such patients are possibly more susceptible to herpes simplex infection than children with milder eczema. The control group was also imperfect in that the controls were not drawn from exactly the same geographical area as the-patients, they were not matched for social class, and some of them possibly had eczema.

The results showed that there was no significant difference between the overall herpes simplex seropositivity rates of the two groups, which were similar to those reported for Edinburgh children in $1967 .^{3}$ Our findings suggest that children with atopic eczema are no more likely to acquire herpes simplex infection than normal children. The severity of initial herpes simplex infections in some children with atopic eczema, combined with troublesome recurrent herpes infections in others, may give rise to a false clinical impression of a greater incidence of infection. Our results do not indicate what proportion of initial herpes simplex infections were subclinical, skin infection, or gingivostomatatis. We have been unable to produce serological evidence to confirm the claim that children with atopic eczema are more often infected with the virus than normal children, ${ }^{4}$ and the general claim that these children are more susceptible to viral infections ${ }^{5}$ requires further substantiation.

We thank Professor Garcia de Lomas, who did much of the laboratory work during a sabbatical visit to the Regional Virus Laboratory, and Professors $\mathbf{M}$ Longson and S Shuster for their helpful comments.

\section{References}

1 David TJ, Longson M. Herpes simplex infections in atopic eczema. Arch Dis Child 1985;60:338-43.

2 Pauls FP, Dowdle WR. A serologic study of herpesvirus hominis strains by microneutralization tests. $J$ Immunol 1967;98:941-7.

${ }^{3}$ Smith IW, Peutherer JF, MacCallum FO. The incidence of herpesvirus hominis antibody in the population. J Hyg (Lond) 1967;65:395-408.

4 Bonifazi E, Garofalo L, Pisani V, Meneghini CL. Role of some infectious agents in atopic dermatitis. Acta Derm Venereol [Suppl] Stockh 1985;114:98-100.

5 Strannegard O, Strannegard IL, Rystedt I. Viral infections in atopic dermatitis. Acta Derm Venereol [Suppl] Stockh $1985 ; 114: 121-4$.

Correspondence to Dr T J David, Department of Child Health, Booth Hall Children's Hospital, Charlestown Road, Blackley, Manchester M9 2AA, England.

Received 10 November 1986

\section{Carbon monoxide concentrations in infant deaths}

\section{S VARIEND AND A $\mathrm{R} W$ FORREST}

Department of Histopathology, Children's Hospital, and Department of Clinical Chemistry, Royal Hallamshire Hospital, Sheffield

for infant deaths in the United Kingdom seem to be unavailable.

SUMMARY Carboxyhaemoglobin measured in 50 infant deaths showed no significant difference between home and hospital deaths nor between explained and unexplained deaths. Carbon monoxide toxicity is unlikely to have an important role in the pathogenesis of sudden infant deaths. The generally low carboxyhaemoglobin concentrations are probably due to endogenous production.

Carbon monoxide poisoning as a factor in the pathogenesis of sudden infant death has been questioned. ${ }^{1}$ Previous studies have been limited to North America, ${ }^{23}$ and carboxyhaemoglobin values

\section{Patients and methods}

A consecutive series of 50 infants who died in South Yorkshire aged 1 week to 2 years was studied between January and November 1985. There were 12 hospital deaths with ascertainable cause (group A), 11 explained deaths at home (group B), and 27 unexplained deaths at home (group C). The boy to girl ratios in groups $\mathrm{A}, \mathrm{B}$, and $\mathrm{C}$ were $4: 8,4: 7$, and $17: 10$, respectively. In group $A$ the duration of admission to hospital varied from one day to one year. 